\title{
Impact of Chemical Weapons on West Bank and Gaza
}

\author{
Rubel Mittal
}

\section{INTRODUCTION}

Due to the long period of Israel's occupation of West Bank and Gaza, people suffered a huge loss of life and property. The policies of Israel violated all the International laws and conventions. In spite of this, Israel always justified its stand in the International lobby. Here the point to be noted that West Bank and Gaza were not the only victim, Israel had conducted hostilities in Lebanon in 2006 and that time it blamed Hezbollah for its use of bombs and cluster munitions on civilians. Although Human rights Watch rejected all the justifications, which was given by Israel during the Lebanon war:

"Many of the attacks in which civilians died took place at a time when there was no evidence that Hezbollah fighters or weapons were in the vicinity, despite IDF claims that the high proportion of civilian deaths in Lebanon was due to Hezbollah hiding its rockets and fighters in villages and towns."

This was not the first incident of this type, when Israel breached all the conventions and laws, and treating the civilians of another country as a butcher. "Operation cast lead" was another grave step of Israel against the people of the Gaza. Even if the death toll could vary in both these mentioned attacks, but the act remained same. The only difference was, the presence of Hezbollah, that time which had propelled Israel to cause violent attacks on Lebanon,now was replaced by Hamas,to incite the same violence on the people of West Bank and Gaza. Israel, suddenly started artilleries and munitions in the Gaza, on December 27, 2008, which ended on 18 January, 2009. This big hunt was named "Operation Cast Lead". It must be noted that, this was not the first attack by Israel on Gaza as the residents of this area already were facing acute shortage of basic needs, and were living in crisis due to the blockade by Israel since 2007 .

However, it is said to be one of the horrible attack on Gaza since 1948, as Israel used all of its munitions ranging from the bombs to White phosphorous, and targeting civilians without any mercy. Many reports confirmed the presence of white phosphorous used during "Operation Cast Lead" apart from drones, missiles, etc., on the over-populated areas of Gaza. The heavy toll of human life, about 1,414 people, out of which 1,177 civilians were killed ${ }^{2}$, were reported.This large percentage of civilians, 83 percent has large enough,to show Israel's unlawful act and intentions during this war.

Every war has its effects on the society and its people. "Operation Cast Lead" had a major impact on the people living in these territories.They would rebuild their homes, but the lives, that have destroyed during the attack could not be mended anyway.

\section{IMPACT ON EMPLOYMENT}

After the hostile atmosphere, Gazans could not recover even after so many years. Still, most of the people have been struggling to meet their daily ends . During the attack,all of the area had been converted into rubble, people could not understand from where they should start. The early closure and restrictions on the movement of people and goods, by Israeli authorities had already been producing worsen poverty, which were raised more by the operation. It sharply elevated unemployment, and made the situation more drastic.

According to the Gaza Chamber of Commerce, the employment reached 44 percent in April 2009. ${ }^{3}$ They then calculated, that due to severe closure and restrictions, there was a loss of many jobs. Although, there was not very good, but the relatively better situation prevailed before the imposed restrictions on Gaza by Israel. This has been proved by the Fafo Institute for Applied International Studies ${ }^{4}$.

According to them the employer status before the 2007 blockade was different as they calculated that; Palestine authorities have 40 percent of the employer, private sector have 23 percent, Self employment has 22 percent share, Hamas government have 6 percent, UNRWA have 5 percent, Israel has 4 percent and NGO's and International aid organizations have 2 percent share of the employer.

By analyzing this trend, it can be said that before 2007 blockade, the civilians of Gaza were engaged majorly in PA, the percentage of the private sector and self employment were also shared a large proportion, and the other small ratio was engaged in other miscellaneous employments. Fafo Institute for Applied International Studies, also made the comparison of the situation after the blockade, according to them:

The significance of private sector jobs and self-employment dropped and the percentage of the Hamas government as an employer increases by two fold. In December 2008, before the Israeli attack on Gaza, 12 
percent of the labor force was employed by the local authorities and 42 percent received their salaries from the PA. This shows that the Israeli labor market was out of reach. ${ }^{5}$

This statistic, indicated that after the blockade, the Israeli market could not be accessed by Gazans, so they switched to another employer, like Hamas and PA. Even the significance of Hamas after the war has been increased, as 13 percent of the labor force were worked there. After the war all other employers, remained in a stable condition, somewhat the increased share goes with UNRWA, which was 7 percent of the labor force on its payroll. A slightly smaller share had jobs in the private sector or were self employed than before the war (19 and 18 percent respectively). ${ }^{6}$

This clearly indicates that during the war, people were unable to go out for jobs as their property had vanished during attacks, simultaneously there self-employment percentage got reduced, along with the private sector. It seems that not only the war, but the long blockade by Israel had worsened the situation as there were no access of things from the outside. Not only this, the closure had also badly hit farming families, which made over a quarter of Gaza's population. Exports of strawberries, cherries, tomatoes and flowers which was used to be an important source of income in peacetime had felt a serious jolt.

The closure had already blocked all the exports, imports, making the life of farmers standstill. Then, the military strikes, transformed the situation, and more worsened as they uprooted thousands of citrus, olive and palm groves, including those far inside the Gaza strip. They also destroyed irrigation systems, wells and greenhouses.

According to the ICRC, many farmers were being denied access to their farming land because of the Israeli-imposed "no go" zone on the Gaza side of the border fence with Israel. At least 30 percent of the arable land in Gaza lies within this buffer zone, which can extend up to one kilometer from the fence.

ICRC claimed that farmers feeling unsafe on their land as they were unsure about the Israel's intention, whether they again would start the war, and again their land could be occupied. They had no material for repair, all the industries crushed completely, fishing zones were barred, leading to soaring of the rate of unemployment.

The World Bank stated in its quarterly report in October 2008, that due to blockade of Gaza only about 2 percent of industrial establishments were still functioning. Industrial employment had fallen from 35,000 in 2005 to a mere 840 , and 40,000 jobs in agriculture had been destroyed. ${ }^{8}$ This was a first glimpse of the occupied territories before the worst nightmare "Operation Cast Lead". It could be imagined easily, then, that if the condition before the December 2008 had been like this, there is no surprise that after the operation, the situation would go out of control.

\section{IMPACT ON EDUCATION}

The education system of Gaza, virtually got a worst hit from all military operations by Israel. Students suffered mental harassment when their family members and loved ones became victim of the operations. Many of them lost their brother, sister or the closest member of the family in these strikes, consequently they could not concentrate in their studies and academics. This has been shown by many reports where the students situation was compared with the situation before the attack ,the variation in mental state is clearly observed .Students after the military attack could not remain in normal condition and have panic attacks when asked by someone about the attacks. They felt pain and sadness.

Table 1.1 : Psychosocial Distress

\begin{tabular}{|l|c|c|c|c|c|}
\hline Some or most of the time & Primary & Preparatory & Secondary & University & Total \\
\hline Not feel safe at school & $36.4 \%$ & $59.5 \%$ & $62.9 \%$ & $67.2 \%$ & $57.4 \%$ \\
\cline { 2 - 7 } & $(\mathrm{N}=449)$ & $(\mathrm{N}=1253)$ & $(\mathrm{N}=1204)$ & $(\mathrm{N}=686)$ & $(\mathrm{N}=3592)$ \\
\hline \multirow{2}{*}{$\begin{array}{l}\text { Not feel safe going to and coming home } \\
\text { from school }\end{array}$} & $59.4 \%$ & $69.0 \%$ & $67.9 \%$ & $69.0 \%$ & $66.8 \%$ \\
\cline { 2 - 7 } & $(\mathrm{N}=730)$ & $(\mathrm{N}=1456)$ & $(\mathrm{N}=1300)$ & $(\mathrm{N}=695)$ & $(\mathrm{N}=4181)$ \\
\hline Worry there will be another war & $79.1 \%$ & $77.2 \%$ & $76.3 \%$ & $71.8 \%$ & $76.5 \%$ \\
\cline { 2 - 7 } & $(\mathrm{N}=974)$ & $(\mathrm{N}=1612)$ & $(\mathrm{N}=1461)$ & $(\mathrm{N}=689)$ & $(\mathrm{N}=4750)$ \\
\hline \multirow{3}{*}{ Have bad dreams } & $77.2 \%$ & $72.7 \%$ & $71.6 \%$ & $61.3 \%$ & $71.4 \%$ \\
\cline { 2 - 7 } & $(\mathrm{N}=952)$ & $(\mathrm{N}=1535)$ & $(\mathrm{N}=1371)$ & $(\mathrm{N}=617)$ & $(\mathrm{N}=4475)$ \\
\hline Feel said & $81.6 \%$ & $84.3 \%$ & $88.6 \%$ & $87.8 \%$ & $85.7 \%$ \\
\cline { 2 - 7 } & $(\mathrm{N}=1007)$ & $(\mathrm{N}=1776)$ & $(\mathrm{N}=1696)$ & $(\mathrm{N}=885)$ & $(\mathrm{N}=5364)$ \\
\hline
\end{tabular}


Impact of Chemical Weapons on West Bank and Gaza

\begin{tabular}{|l|c|c|c|c|c|}
\hline Feel nervous & $76.2 \%$ & $81.6 \%$ & $86.3 \%$ & $86.2 \%$ & $82.7 \%$ \\
\cline { 2 - 7 } & $(\mathrm{N}=941)$ & $(\mathrm{N}=1717)$ & $(\mathrm{N}=1650)$ & $(\mathrm{N}=868)$ & $(\mathrm{N}=5176)$ \\
\hline \multirow{3}{*}{ Treated badly by other students } & $46.8 \%$ & $51.9 \%$ & $32.6 \%$ & $20.4 \%$ & $39.9 \%$ \\
\cline { 2 - 7 } & $(\mathrm{N}=576)$ & $(\mathrm{N}=1093)$ & $(\mathrm{N}=624)$ & $(\mathrm{N}=205)$ & $(\mathrm{N}=2498)$ \\
\hline \multirow{3}{*}{ Fight with other students } & $32.6 \%$ & $42.5 \%$ & $29.0 \%$ & $16.7 \%$ & $32.2 \%$ \\
\cline { 2 - 7 } & $(\mathrm{N}=402)$ & $(\mathrm{N}=895)$ & $(\mathrm{N}=555)$ & $(\mathrm{N}=168)$ & $(\mathrm{N}=2020)$ \\
\hline Feel angry & $60.8 \%$ & $76.8 \%$ & $80.1 \%$ & $75.4 \%$ & $74.4 \%$ \\
\cline { 2 - 7 } & $(\mathrm{N}=751)$ & $(\mathrm{N}=1620)$ & $(\mathrm{N}=535)$ & $(\mathrm{N}=760)$ & $(\mathrm{N}=4660)$ \\
\hline Not hopeful about the Future & $26.3 \%$ & $38.2 \%$ & $48.5 \%$ & $71.8 \%$ & $44.4 \%$ \\
\cline { 2 - 7 } & $(\mathrm{N}=324)$ & $(\mathrm{N}=806)$ & $(\mathrm{N}=928)$ & $(\mathrm{N}=721)$ & $(\mathrm{N}=2779)$ \\
\hline
\end{tabular}

Source : Psychosocial Assessment of Education in Gaza and Recommendations for Response", Report on the findings of an assessment conducted by Kathleen Kostelny, Ph.D. and Michael Wessells, Ph.D. of the Columbia Group for Children in Adversity, Sept.2010 UNESCO, http://www.unispal.un.org/UNISPALNSF/0/C9AF039F6045BOOC55257876006ECAF7.

These figures indicate that primary student's major concern is about the war, they always would be in a panic to have war again, on the same side, their feeling of sadness is matchable with university level students showing that how they were becoming mature in their early age. Students who were going to school and university were depressed about their education level. They could not think of anything, except war and war crimes. They always considered their education was of no use, as there were no growth opportunities in Gaza and their neighburhood areas.

Students felt pain and nervousness when they recalled the fearful days.

Fig.1.2 : Feelings Nervous by Educational Level (Percentage of learners)

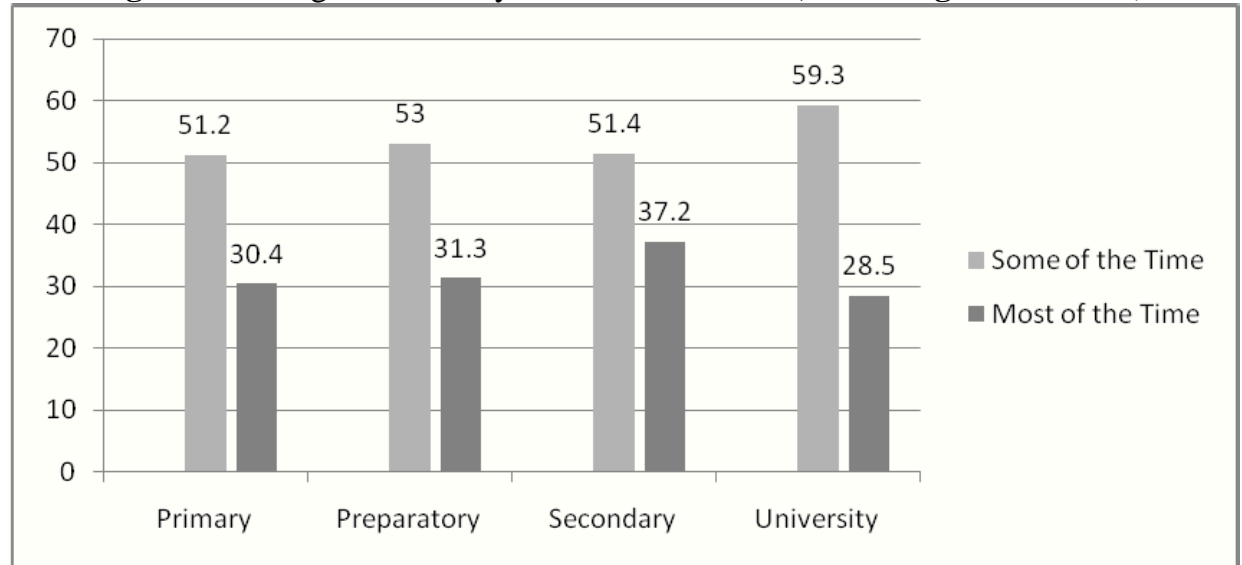

Source : Psychosocial Assessment of Education in Gaza and Recommendations for Response", Report on the findings of an assessment conducted by Kathleen Kostelny, Ph.D. and Michael Wessells, Ph.D. of the Columbia Group for Children in Adversity, Sept.2010 UNESCO, http://www.unispal.un.org/UNISPAL-NSF/0/ C9AF039F6045B OOC55257876006ECAF7

These figures entails the irony of university students who were not seeing any future after the completion of their studies. Due to continuous blockage and offense, their years were badly hit, and their growth opportunities ceased.It increased the mental pressure and thereby they got nervous. This report says that , they felt zero and black most of the times. They could not be happy as the war related disorders prevailed in their mind.Here again the university students felt more sadness than other students in some of their time, the reason might be they were cut off from the world, and they could not make their education worthful for their parents and family.

But on the same side, the secondary students felt sadness in most of the time in large proportions. This might be due to the reason, as they are full mature to felt and see the agony of the war, they could not get out of the nightmare of the destruction. When the studies were done to check out the real issues of the students after the war then the trend found that the university students were more concerned about their tuition money, as all 
the monetary funds were stuck by Israeli army's, operation and their own money sources were badly hit by the military operation. Similarly, most of them worried for their low academic achievement, as they suffered since long and when they thought of going abroad for the studies, some obstruction would come, in the form of closure and military attacks. This has been shown by this report.

Fig.1.3 Biggest Concerns of University Students (Percentage of Students)

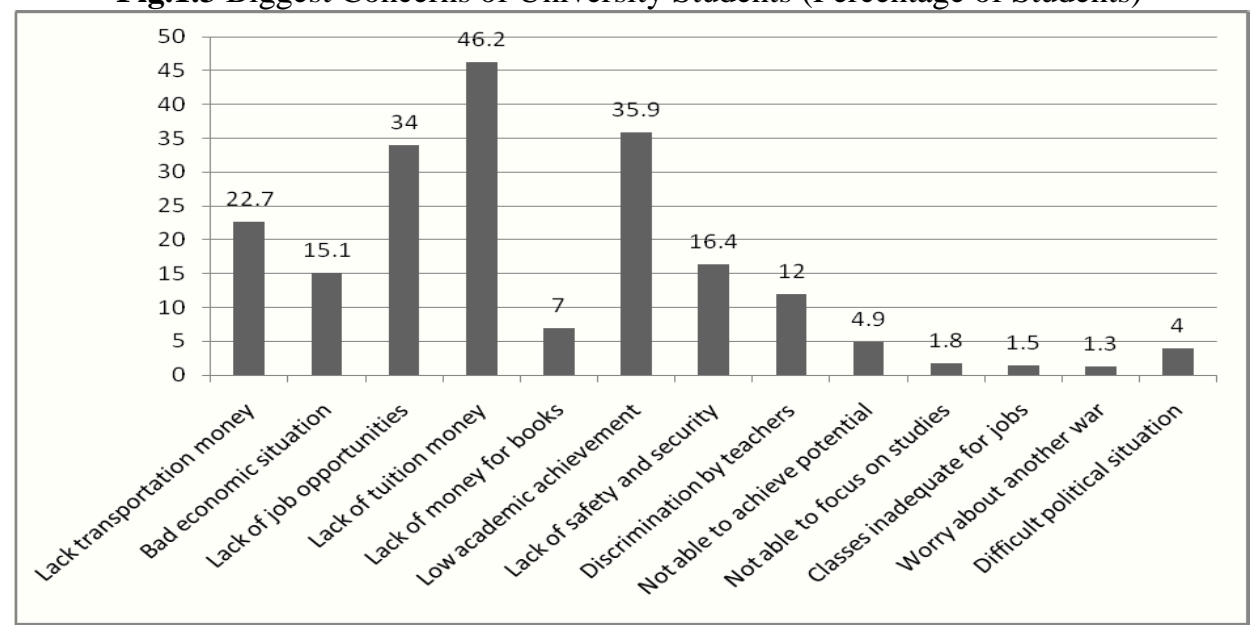

Source : Psychosocial Assessment of Education in Gaza and Recommendations for Response", Report on the findings of an assessment conducted by Kathleen Kostelny, Ph.D. and Michael Wessells, Ph.D. of the Columbia Group for Children in Adversity, Sept.2010 UNESCO, http://www.unispal.un.org/UNISPAL-NSF/0/ C9AF039F6045B OOC55257876006ECAF7 It shows that students who were in university ,had the most concerned issue of finance.

Fig. 1.4 Learners Reporting that they are "Not at All Hopeful About the Future" by Educational Level (Percentage of Learners)

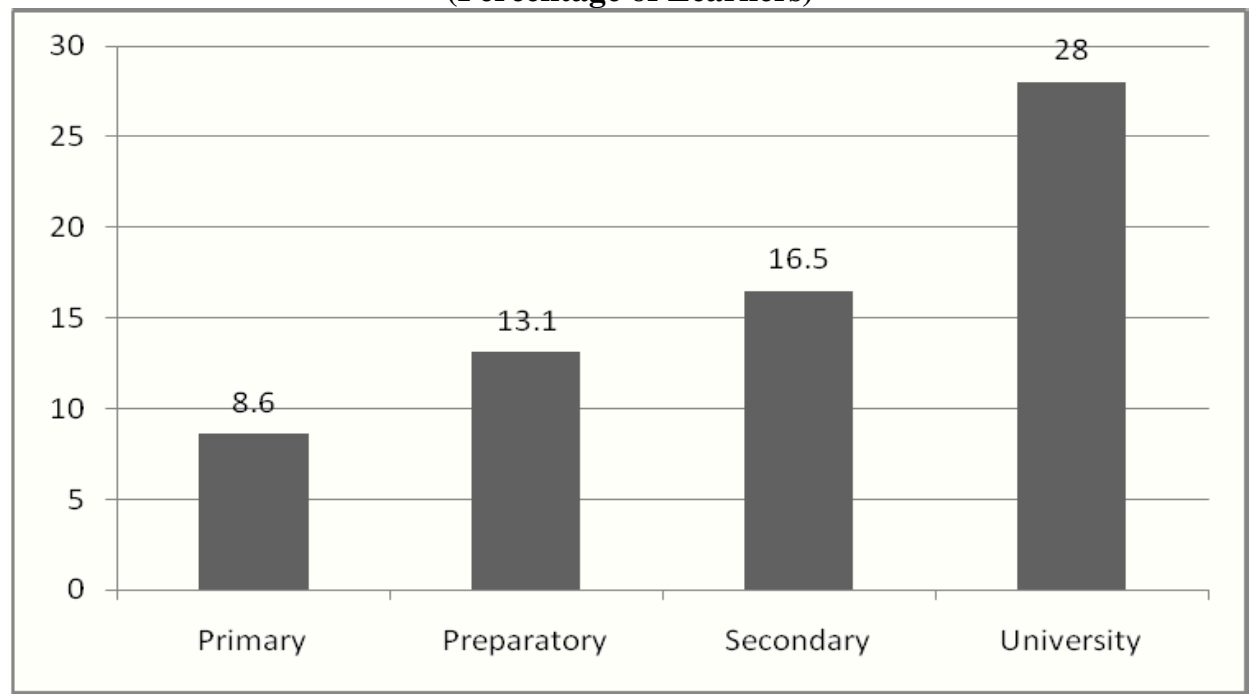

Source : Psychosocial Assessment of Education in Gaza and Recommendations for Response", Report on the findings of an assessment conducted by Kathleen Kostelny, Ph.D. and Michael Wessells, Ph.D. of the Columbia Group for Children in Adversity, Sept.2010 UNESCO, http://www.unispal.un.org/UNISPAL-NSF/0/ C9AF039F6045B OOC55257876006ECAF7

The same trend resulted from this study, the sense of insecurity relied in university students. They could not see their future. They could not access advanced educational level, they could not afford books, tuition fees, and this is the obvious reason for their hopelessness as whenever they wanted to stand, they were bulldozed by Israeli's army. University students were responded on being asked what they would do after ten years, many of them answered, that they were not specialized in any of the field, many of them are uncertain about their specialisation. This shows that inspite of the unlawful destruction and devastation, their hope would not be much ended, as this spirit might be give courage to stand the Gazans once again. But the trend were 
more hopeless for secondary and preparatory students, on being asked the same question, they responded that they were not sure about their future, especially secondary students, showed the uncertainty and very less percentage showed that they would like to go to university for further education. Only 33.1 percent would think to be professional than 53.3 percent of preparatory students. ${ }^{9}$ So the major victims were secondary students as they could not forget the war crimes.

\section{IMPACT ON HEALTH}

According to WHO, health services also suffered from attack.15 of the 27 hospitals were damaged .Primary care centers were damaged as many as 43.29 ambulances were damaged or destroyed, many health staff was killed and about 25 were injured. WHO reports clearly mentioned that before June 2006 the health status of the Palestinian people was good by regional standards. But after it due to severe blockade by Israel, the life conditions of people were deterioted and then the use of chemical weapon had made the condition worsen. Infants and child mortality had increased. There was evidence of childhood stunting, anemia affecting nearly half the children under 5 years(and in child bearing women) and low births weights increased from $4 \%$ in 2002 to $7.3 \%$ in $2006 .{ }^{10}$

There were evidences of profound psychological distress from many years of conflict and blockade .The increased risk of long term mental health problems as a result of the conflict, were added up by worsening socio-economic and society conditions and the reduced quality of life made the people condition miserable. During operation cast lead patients were suffering from burning by white phosphorous. Doctors discovered that burning continued even after initial medical care if phosphorous pieces were remained inside and again were exposed to air.

Immediately after Operation cast lead UNFPA conducted a study of monthly service records and rapid assessment in four major hospitals, secondary analysis of Minister of Health operation rooms reports and feedback from key informants in UNRWA shelters, hospitals and communities in Noth gaza, Rafah and Khan Younis governates. ${ }^{11}$ The main findings are;

1. A $40 \%$ increase in miscarriages cases admitted to maternities.

2. A $50 \%$ increase in neonatal deaths (data from shifa hospital maternity)

3. An increased prevalence of obstetric complications.

United Nations reports illustrated the sufferings of women caused by the feelings of inability to provide children with the care and security they needed. The military operations and increased poverty add to the potential for conflicts in the family and between widows and in laws. This lead to mental health deteriotion during operation cast lead. Adult's demonstrated symptoms of profound fear and depression while their children showed characteristics of disturbances such as insomnia and bed wetting. Another study - a household interview study of some 2000 households carried out 3-12 march 2009- interalia revealed that $15 \%$ of children started bed wetting during the military attack, some $20 \%$ of children had problem of concentration that started during the attacks; $55 \%$ of the population felt as if the war actions were still going on ,some $40 \%$ felt very nervous, very angry, depressed $\backslash$ or so deeply homeless that they thought things would never get better. These signs of psychological distress were as prevalent in 18-24 year olds as in the rest of the population. ${ }^{12}$

Apart from the mental trauma during the war, Israel tightened its hold on the west bank by increasing expropriations, house demolitions and demolitions orders, granting more permits for homes built in settlements and intensifying the exploitations of the natural resources in the west bank. ${ }^{13}$

After the chemical weapons attack in Gaza there was a serious damage to the health facilities and services especially maternal and newborn services. Surveyed facilities reported a $31 \%$ increase in miscarriage cases admitted to maternity ward during the conflict, one hospital reported a $50 \%$ increase in neonatal deaths. ${ }^{14}$ According to the report by UNFPA some 5000 deliveries occurred in medical facilities in January compared to an average of 4000 deliveries per month prior to the crises. The increase which does not include deliveries that occurred outside of a medical facility may reflect premature deliveries resulting from stress and shock. ${ }^{15}$

Gaza's health-care system was not so technologically advanced as the systems in other countries. The reason was the blockade by Israel for the supply of medical items, Israel hampered the supply of basic amenities like painkillers and other simple medicines. So the question is out of the mark for the advanced items. Patients have to wait for a long time to get the access of medical treatment outside Gaza. Seriously ill patients, sometimes have to wait for months to get the official papers clear.

"I have a pancreatic tumour. At first, there was hope that I would be given an operation, but as time went by I stopped hoping. I am in pain and I know all too well that my disease is life threatening." ${ }^{16}$ This has been not only a single story, the insulin-dependent patients and those on dialysis were prone to danger when the treatment was not done in time. Israel constantly decreased the ratio of the people who were referred to the outside for medical aid, since 2006. This was studied by WHO "The proportions of referred patients who were denied exit by Israel increases from 10 percent in 2006 to 44 percent in the first six months of $2008 .{ }^{17}$ 
Even when patients obtained the permission to leave, the transfer through the Erez Crossing Point is a difficult task. Patients on life-support machines have to be removed from ambulances and placed on stretchers, then carried 60-80 meter through the crossing to ambulances waiting on the other side.

Patients were already exhausted from the travelling, and then these restrictions put by Israel not allowing the ambulances made them very hopeless. They were on life-supporting system, and the policies of Israel and their soldiers were not treated them like the normal human being. According to Fafo Institute, people who were abruptly ill or suffered from war injuries, could not receive medical treatment, due to the following reasons ${ }^{18}$ :

35 percent said they did not require treatment or care, 26 percent said it is too dangerous to reach hospital or clinic, 10 percent complain of facilities, 10 percent told about their non-affordable capacity, 10 percent said the lack of nearby facility, 4 percent done their self-treatment and 5 percent are counted in other reasons.

\section{Impact on Physical Infrastructure}

During the "Operation" public infrastructure and homes sustained extensive damage.

According to the United Nations (UN) damage assessment carried out using satellite imagery, 2692 buildings and 180 greenhouses were destroyed and 167 kilometers of road were damaged. The assessment revealed 220 impact craters on roads and bridges and more than 700 craters on open or agricultural land. ${ }^{19}$ It means that all the infrastructure and amenities have been bulldozed by the Israeli military. The sewage systems which had already in dire state, were on the verge of an end.

On Jan.7 World Bank warned the public, who were living near a sewage lagoon, to leave the place as there might be the chances of flooding, as the infrastructure were became fragile, due to continuous bombing and explosions. ${ }^{20}$ Reports showed that because of the fighting there were no functioning sanitation services, including solid waste disposal. ${ }^{21}$ "Solid Waste is piling up in the streets of Gaza" OCHA reported on January $9 .^{22}$ This situation was prone to many contagious diseases. People were living in shelters and camps, which were over-crowded and due to destruction of properties, they suffered a lot. Although chlorine was used to disinfect the water, the risk of sewage and other waste material seeping into the water supply network represented a major threat to public health.

According to the ICRC report, "Everyday, 69 million litres of particularly treated or completely untreated sewage - the equivalent of 28 Olympic - size swimming pools - are pumped directly into the Mediterranean because they cannot be treated". ${ }^{23}$ Attacks on January 2, shut down six of ten power lines coming into Gaza from Israel and of the 2 power lines coming from Egypt. On January 3, all of Gaza city and most of northern Gaza was without electricity and Rafah had limited electricity. ${ }^{24}$ According to Gaza's electricity company (GEDCO), as of January 7, five out of 10 electricity lines from Israel were still not functioning.

This means that Gazans were not receiving electricity, during and after attacks as the lines were hit badly. This was confirmed by UN. "The majority of Gazans experienced power cuts up to 32 hours a week, and more than 40,000 people remain without electricity. ${ }^{25}$ There seems to be not the end of their plight. The fighting created roughly 600,000 tons of concrete rubble, but Israel has allowed only 41 truckloads of reconstruction materials into Gaza over the past year - about 4 truckloads a month, this was not a good figure, compared to the five months before the blockade at that time Israel allowed an average of 7,400 truckloads of construction material into the Gaza each months. ${ }^{26}$ The destruction by military had made a serious impact on the health facilities. People were cut off from the medical aid, the ambulances were damaged. Most of the equipment was unreliable and in a dire state. Various machines like CT Scanners, and even X-ray machines were not in the hospitals, and if it was there, it was not in a working condition. This induced the risk of the patients who were supposed to get medical equipments. So, we can think of the loss of infrastructure that left the civilian's life in danger. New born babies could not get ventilators as the Israel did not allow to enter into the war zone territories.

\section{Impact on Environment}

The military operations resulted in extensive casualties and the destruction of homes, livelihoods and infrastructure. The long standing restrictions, siege and then the massive military action posed a serious concern for the civilian's life. Because of limited infrastructure and the inadequate treatment of raw sewage, it has been discharged directly into the Mediterranean along the coast of the Gaza strip. This created a major environmental catastrophe for the nearby people of this zone.

\section{Israel's stand}

Israel seemed to be inert when being asked for the investigations of the use of white phosphorous. Human Rights Watch reported in their report that in the case of Operation Cast Lead - Israel's military investigators already found that their soldiers and commanders done no wrong, even before the investigations are complete. They quoted Col. Liron Liebman (who became head of the IDF's International Law Department after (Operation Cast Lead). ${ }^{27}$ 
"Commander during the fighting shouldn't be losing sleep because of the investigations. It's impossible not to make mistakes in such a crowded environment, under pressure". He added "War crimes charges brought against Israeli soldiers and commanders are "Legal terrorism".

It has been not a matter of surprise that the senior officer of Israel had given such statements, Israel's track records has numerous such examples where it consider its crimes as "legal terrorism".

\section{Displacement Evidenced by "Operation Cast Lead"}

Israeli's destruction led to the residents of the city displaced in large numbers, according to the survey done by Fafo Institute ${ }^{28}$,

seven in ten thousands (71 percent) stayed behind and remained in their dwellings during the entire Israeli attack. While three in ten households $(29$ percent) left their homes and went to live elsewhere. The large proportion of the Gazans returned back to their houses after the attack, the percentage is about 28 percent, while 1 percent had not gone back nearly two months after the attacks.

If the vast destruction of homes were in large proportions, people must be displaced and must be living in shelters or refugee camps. Over 4,000 housing units were totally destroyed leaving 26,000 people without homes, and over 11,500 housing units were damaged, resulting in a future 75,000 people either displaced or living in every difficult conditions. ${ }^{29}$ The survey done by Fafo Institute for Applied International Studies has the following figures :

When they were asked why they left their homes during war, they had the following answers. ${ }^{30}$

Felt the living area to be unsafe (95 percent), partly damaged dwelling (17 percent), completely damaged dwelling (3 percent), forced to move by soldiers (3 percent), wanted to be closer to relatives ( 2 percent), wanted to be nearer to a health facility (1 percent). The answer's trend seems that they were moved as they felt unsafe in their present homes. There are always fear of attack from Israel, little percentage goes with the need of health facility, which they wanted to be near with them. But the main reasons the feeling of unsafety and the damaged part of their homes which led to fled their homes.

UNRWA reported that only 20,000 people were living in temporary shelters untill April 1, most of them still living with their relatives or friends. ${ }^{31}$ World Health Organization showed anxiety over this situation as very large number of people were living in temporary shelters, which had limited supply of basic amenities, leading to spreading of various types of communicable diseases. The lack of essential nutrients in the diet were made them prone to several disorders.

People have to reduce the food intake as the supplies were very limited inspite of the supply by many sources. This has lead to the large number of anaemic and malfunctioning disorders. Even the situation was not good before the war, WHO and UNICEF reported that about one third of children under five and women of child-bearing age had iron deficiency anemia before the blockade, about 10 percent of children under five shows signs of stunting. ${ }^{32}$ It can be analysed that if the situation before the blockade is worst, then how can we expect the good one after the inhumane war and disaster.

\section{Impact on Economy}

The economy of Gaza suffered a serious hit during the attacks. During the blockade, Gaza suffered a heavy price, as the conditions were continuously deteriorated in that period The destruction and damaged caused by "Operation Cast Lead" would hamper future economic recovery as the infrastructure had completely damaged. It can be shown from this table the extent of destruction.

Table1.5: Destruction of other Commercial and Public Premises

\begin{tabular}{|l|c|c|}
\hline Type of Establishment & Percentage & Number \\
\hline Bank & 0.16 & 1 \\
\hline Place of Worship & 22.15 & 136 \\
\hline Market & 0.16 & 1 \\
\hline Company & 2.77 & 17 \\
\hline Community Based Organisation & 7.49 & 46 \\
\hline Educational institution & 25.90 & 159 \\
\hline Health Institution & 3.26 & 20 \\
\hline Police station & 7.98 & 49 \\
\hline Ministry department & 11.07 & 68 \\
\hline Political party offences & 0.49 & 3 \\
\hline Political faction premises & 2.61 & 16 \\
\hline Executive Forces premises & 0.81 & 5 \\
\hline Other & 15.15 & 93 \\
\hline Total & 100 & 614 \\
\hline
\end{tabular}


Source : "Operation Cast Lead : A Statistical Analysis, Al-Haq August 2009 <http://www.alhaq.org/pdfs/gazaoperation-cast-lead-statistical-analysis\%20.pdf

We could analyse by this figure, the public properties were badly damaged. All the public infrastructure like police station, Education Institution, Ministry Department suffered a heavy jolt. So it has been very difficult for Gaza to recover from it. People were unemployed in a large scale, unemployment rose in the Gaza strip to some 70 percent in the second quarter of $2008 .{ }^{33}$ If all the sectors had been hit, the rate of unemployment would also rise, and it was exactly happening. According to Fafo Institute, the economic situation in Gaza continued to deteriorate with Israel's armed attack. When they surveyed and asked the residents about the present situation compared with the situation before the attacks. They found the following percentage ${ }^{34}$;

Household economy had worsened (63 percent), Household economy had remained the same (35 percent), Household economy had improved (2 percent). Majority of the households told about the worsening economic condition, from the attacks. And it was due to the reason that the basic amenities that could be provided before attacks were also banned from Israel. Blockade had restricted the import of goods and basic items to the some extent, but militarisation made the hundred percent cuttedoff.

It was estimated by the Palestine Trade Centre (Pal Trade) that the civilians in Gaza needed imports of various items, making the need of some 850 truckloads per day (some 800 for the private sector alone, according to the Palestinian Private Sector Coordinating Council) i.e. some 5950 per week or some 25500 per month. ${ }^{35}$ This showed that due to the attack, Gazans were in desperate need of basic items for their livelihood, but Israel's imposition could not allow them to access it. Gazans were desperate about their situation, when the Fafo Institute in its household survey asked them,

If they need urgently 1,000 rupees, how will they able to raise the money in a week the answers shows the extent of their hopelessness for future, most of them told, it is impossible are them (60 percent), some are doubtful (7 percent), some are still in hope to draw the money from savings (11 percent), some rely on family and friends (20 percent), and some told them to draw the money from savings clubs and other sources (2 percent). ${ }^{36}$

The trend of answers given by household reflected that most of them did not see any source of income. All banks, buildings were collapsed, and their jobs had been lost, their land was made barren by Israeli's attacks.

Table1.6: Factories Damaged or Destroyed by Type of Industry, Number of Employees

\begin{tabular}{|l|c|c|c|c|c|c|c|c|}
\hline \multirow{2}{*}{$\begin{array}{l}\text { Type of } \\
\text { Industries }\end{array}$} & \multicolumn{2}{|c|}{$\begin{array}{c}\text { Number of } \\
\text { factories affected }\end{array}$} & \multicolumn{2}{|c|}{$\begin{array}{c}\text { Number of } \\
\text { employees before } \\
\text { offensive }\end{array}$} & \multicolumn{2}{|c|}{$\begin{array}{c}\text { Number of } \\
\text { employees after } \\
\text { offensive }\end{array}$} & \multicolumn{2}{c|}{$\begin{array}{c}\text { Number of employees } \\
\text { laid off as consequence }\end{array}$} \\
\cline { 2 - 9 } & $\begin{array}{c}\text { Total } \\
\text { damage }\end{array}$ & $\begin{array}{c}\text { Partial } \\
\text { damage }\end{array}$ & $\begin{array}{c}\text { Total } \\
\text { damage }\end{array}$ & $\begin{array}{c}\text { Partial } \\
\text { damage }\end{array}$ & $\begin{array}{c}\text { Total } \\
\text { damage }\end{array}$ & $\begin{array}{c}\text { Partial } \\
\text { damage }\end{array}$ & $\begin{array}{c}\text { Total } \\
\text { damage }\end{array}$ & \multicolumn{2}{c|}{$\begin{array}{c}\text { Partial } \\
\text { damage }\end{array}$} \\
\hline Plastics & 0 & 3 & 0 & 34 & 0 & 18 & 0 & 16 \\
\hline Wood & 9 & 11 & 103 & 159 & 16 & 87 & 87 & 72 \\
\hline Food & 19 & 12 & 168 & 120 & 24 & 140 & 144 & 180 \\
\hline Electrical & 2 & 3 & 90 & 19 & 0 & 5 & 90 & 14 \\
\hline Chemical & 6 & 7 & 41 & 84 & 0 & 44 & 41 & 40 \\
\hline Mineral & 27 & 36 & 266 & 401 & 29 & 224 & 237 & 177 \\
\hline Garment & 8 & 15 & 124 & 144 & 0 & 22 & 124 & 122 \\
\hline Construction & 31 & 22 & 490 & 431 & 19 & 39 & 471 & 392 \\
\hline Total & 102 & 109 & 1282 & 1592 & 88 & 579 & 1194 & 1013 \\
\hline
\end{tabular}

Source : "Operation Cast Lead : A Statistical Analysis, Al-Haq August 2009 <http://www.alhaq.org/pdfs/gazaoperation-cast-lead-statistical-analysis\%20.pdf

These figures entailed the people's situation in a specific parameter, where they worked for many years, these factories were damaged or not in a position to employ these people. Large number of people became unemployed, mostly from construction companies. Because these companies were supposedly hit by two factors. First the direct attack from Israel, another one, was the restriction of trucks, by Israel which carried the material for construction. This was established by the weekly report of COGAT for 26 April - 2 May, they listed the total number of trucks that was allowed in Gaza during that week to be 438(which is very very less than required). ${ }^{37}$ 
The agriculture sector, which comprised a substantial element in the Palestine's economy, was also severely affected by Israel's military offensive. Farmers who had given seeds, manures, fertilizers were barred and in addition, their land and working tools were collapsed.

All the irrigation systems, greenhouses suffered a major hit which was the source of income of Gaza's population in a peace-time. Farmers have lived in bad condition since the closure of Israel by 2007, as they blocked all the material required for irrigation, for ploughing in the fields. Therefore, farmers have to rely on the local sources to get the essential items. But after the Operation Cast Lead, the situation became out of reach.

Table 1.7 : Direct Losses in the Agricultural Sector

\begin{tabular}{|l|c|l|}
\hline Type of losses & Total losses in the Gaza Strip & Unit \\
\cline { 2 - 3 } & 89 & Number \\
\hline Greenhouse & 184.936 & Area (in dunam) \\
\hline Water-well & 42 & Number \\
\hline Irrigation pool & 142.844 & Area (in dunam) \\
\hline Water pump & 862 & Number \\
\hline Pesticide sprayer & 210 & Number \\
\cline { 2 - 3 } & 34968 & Capacity (in cubic meter) \\
\hline Gates & 219 & Number \\
\hline Livestock & 302 & Number of orchards \\
\cline { 2 - 3 } & 368 & Number of sprayers \\
\hline Warehouse & 735 & Number of orchards \\
\cline { 2 - 3 } & 1038 & Number \\
\hline Birds & 178 & Number of orchards \\
\cline { 2 - 3 } & 8721 & Number of animals \\
\hline Beehives & 205 & Number of orchards \\
\cline { 2 - 3 } & 10405 & Number of warehouses \\
\cline { 2 - 3 } & 191 & Number of orchards \\
\hline \multirow{2}{*}{ : "Opper of birds } \\
\hline
\end{tabular}

Source : "Operation Cast Lead : A Statistical Analysis, Al-Haq August 2009 <http://www.alhaq.org/pdfs/gazaoperation-cast-lead-statistical-analysis\%20.pdf

\section{Women's Psychological Difficulties During the War}

A careful observation on the mental status of women from Gaza states that they were badly affected by war, which resulted into many immediate problems like fear, anxiety, sleeping disorder. They reported panic attacks, depression, sadness and have the fear of death at any moment. Their fear was both for loved ones and for herself, but on going it deeper, we found that the fear of losing the lives of their loved ones such as husband, children, family etc. was more than they feared for their own lives. The reason behind this, probably would be the social structure of the society. Being a patriarchal society, women laid more stress on the lives of their husbands, children as they were dependent on them. Even it has been seen that women who became divorced, during the attacks did not want to remarry because her husband had wish, not to remarry and wants her to look after their children. "My husband asked me not to marry, to look after the children. I said the same to him. I said that if I died as a martyr I would wait for him in paradise. ${ }^{38}$

This reflects the women's irony, who was been tied with the husband's will, even after his death, she could not think of her own life. She became victim of dual torture, one was by the war and another was from domestic front. It has been reported that if children were caught in some mishap during the attacks, she had been blamed for this, for not keeping them safe. As the responsibility of women in Gaza is primarily of child-caring, everyone expecting from her to keep the children out of any mishap and blamed if mishappening occurs to her children.

Nujoud's husband, who is deaf and dumb, blames her for the death of their two sons. "Everyday when the husband sees me, he blames me. Why did I take the children out of the classroom? Everyday he says it is my fault, that I killed my sons." 


\section{Feeling of Insecurity}

No one in the wartime was safe in the midst of heavy bombing and artilleries. But the fear of insecurity was always reported higher in women and children. As they were unable to cope themselves in that environment. In Gaza ,women found no place safe, inside or outside the house. She felt insecure and have a fear of the physical harassment as the soldiers could do anything in that hardships.

The other reason for insecurity, was the fear of losing husbands. They feared to become disabled, as this could be the reason for their husbands to leave them. Women reported of sudden panic attacks during and after the war. They could not express their feelings of grief and sadness, to their husbands and suffered a high range of mental trauma throughout the time. Women who had taken the shelter in refugee camps and tents had clashed for water, food etc. as many people were residing in these camps and women had to take burdens of all responsibilities. This also led to insecurity among them.

\section{Nervousness and Overreaction}

Women felt nervousness, when they thought about the access of medical health services during the war. They expected to die, due to lack of medical facilities there. They felt nervousness when they think about their loved ones, who were stuck in other areas and she could not get to them. She always remained in a traumatic condition, when she could not provide help to their children. This resulted into beating of children, beating of herself without any reason. She asked many times to the people, whether the situation would become right or not?

At night, when there were no electricity and the intensive military operations continued they were more overprotective for their children. Even there was a cases when women was sleeping with her dead children for many days, during the operations.

\section{Sadness and Crying}

Women screamed, when the mental tensions reached to the limit. She could not see her children, who were playing in front of her before one day. She saw the children blood-coated. She saw the children, who were taking last breath in her arms. She cried, and beaten herself. She could not display her feelings to anyone, and eventually screamed for help.

"What we saw on the roof was horrible. All of their bodies were cut in pieces and burned. They were wearing their Eid Clothes. I saw their brains, all their pieces. I tried to carry them, but they were too hot, they were burned. You can't imagine what it was like ..."40

This was the situation from which women had passed. They saw their children and family ones like a butchered meat, but she couldn't do anything. It resulted into sadness and panic attacks.

Women had compelled to use very basic and old mechanism for survival due to cut off of electricity and lack of supplies, they forced to prepare food in very old style and have to do all the works, which were meant for very old lifestyle. This led to sadness among them.

\section{Inability to Protect Others}

Women felt embarrassment for not being able to give help to their children in hard time. She could not protect them from such sufferings. She saw the other women who were in also distress, but she could not lent her hand to help her. Due to siege and war, all the basic amenities supply were cut off, led to lack of water and food. Women did not understand how they provide food and water to the needy ones especially to their little children. This led to the mental depression and insomenia. Women could not sleep properly in night owing to the fear of sudden attacks and due to nightmares. She lost all the sensitivity after seeing such inhumanity. She did not want to live after losing all her loved ones in many cases, and felt unable to recover from it.

"As a result of the attack, and the death of her husband and children, Leila Al-Ir has suffered severe psychological trama. From one month after the attack she was unable to speak, and she currently receives psychological treatment..."

\section{Other Problems :}

As the Gaza society, has completely patriarchal in nature, male has been typically head of the family . In this situation, women has the difficulty to live alone if it became widow during the war. Because either they have forced to return to their own family or forced to remarry. Both options were traumatic for women, as there was no choice left for her. Women could not do what she want. A widow may retain custody of her children, as long as she did not remarry; at the point of remarriage, the custody of the children would revert to the husband's family. 
The other problem that would develop in the life of widow, was the legal right of the property. It was remarkably seen that husband's family would take all of the belongings and property of the son, leaving behind her widow empty handed.

For instance, Masouda, a young widow reported that her father in law had taken all the money given to his son's family. He had taken all the money given to her family, by Hamas and by UNDP as aid after the military attacks." 42

This led to the women in despair and agony, as she could not stand herself independently. Other problems that were encountered by the women, was the lack of privacy for their daily routine. They were forced to live with many people in refugee camps, where there were insufficient bathrooms. Many case studies reported that women used bathroom of their houses which were partially destructed, as the bathrooms in camps lacked privacy and were very less, for this they had to go large distances amidst of military and warlike conditions. It made the women situation became more pathetic.

\section{Killing of Women}

Despite the numerous claim of Israel, it had taken all the possible measures during the operation to avoid any civilian casualty, large number of civilians had lost their lives. Large percentage included women, who were neither Hamas terrorist nor those who could pose danger to powerful Israeli's. According to the Figures, released by the Ministry of Health in Gaza, 118 women were killed and 825 injured. The majority of them were belonged to Northern Gaza strip and Gaza City. ${ }^{43}$ Although women in all parts of the World has benefitted all the protections extended to protected persons under customary IHL and the fourth Geneva Convention. In spite of it, Israel violated all the laws, and done all the crimes on women which have prohibited specifically by the convention on the Elimination of all forms of discrimination against women.

\section{CONCLUSION}

We have seen that Operation Cast Lead left an extremely negative impact on the society of people of Gaza .Large sections of people were cut off from the basic supply of items and goods meant for their survival . The attacks had affected the people all along the line. Everyone was traumatized and suffered mental shock .On a large scale houses were demolished, industries, factories were destroyed that resulted into increased unemployment The economy of Gaza suffered a heavy jolt after the attacks .People were left with no piece of land to cultivate. Children and women were traumatized excessively. Children's schools were damaged, with no positive future in sight. They could not see anything bright. This resulted into depressions and trauma. In this way Operation Cast Lead changed the lives of people and left them in a hopeless situation.

\section{REFRENSES}

[1]. "Rain of Fire, Israel's Unlawful use of White Phosphorous in Gaza", HRW, March 2009, http://www.org/ en/reports/2009/03/25/rain-fire.

[2]. "Through Women's Eyes, A PCHR Report on the gender-specific impact and consequences of operation cast lead", Palestinian Centre for Human Rights, http://www.pchrgaza.org/files/ reports/english/pdf-spcc-through women's\%20-eyes.pdf.

[3]. "Gaza : 1.5 million on people trapped in despair", ICRC, June 2009, http://www.icrc.org/ eng/assets/ files/other/gaza-report-icrc.eng.pdf.

[4]. "Life in the Gaza Strip, six weeks after the armed conflict 27 Dec., 2008 - 17 Jan., 2009. Evidence from a household sample survey- A Summary", Fafo Institute for Applied International Studies, http://www.unispal.un.org/UNiSPAl:NSF/0/5A91FECBD86B30 F085257595B004E178A.

[5]. Ibid.

[6]. Ibid.

[7]. "Gaza - 1.5 million people trapped in despair" ICRC, June 2009, http://www.icrc.org. eng/assets/files. others/gaza.reports-icrc.eng.pdf.

[8]. "Deprived and Endangered : Humanitarian Crisis in the Gaza Strip", Human Right Watch, Jan.13, 2009, www.hrw.org/en/news/2009/01/12 deprived-and-endangered-humanitarian crisisgaza-strip.

[9]. "Psychosocial Assessment of Education in Gaza and Recommendations for Response", Report on the findings of an assessment conducted by Kathleen Kostelny, Ph.D. and Michael Wessells, Ph.D. of the Columbia Group for Children in Adversity, Sept.2010 UNESCO, http://www.unispal.un.org/UNISPAL-NSF/0/C9AF039F6045BOOC55257876006ECAF7. 
[10]. Director General of primary health care, personal communication WHO cited in "WHO SPECIALISED health Mission to the gaza strip", http://www.who.int/hac/crisis/international /wbgs/gaza-specialized-mission-extendedrep-21may09.pdf extended report 21 may 2009.

[11]. "Gaza crises ; impact on reproductive health especially maternal and newborn health and obestric care" ,draft report,Jerusalem ,United nations population fund, 10 Feb 2009 cited in "WHO SPECIALISED health Mission to the gaza strip", http://www.who.int/hac/crisis/ international/wbgs/gaza-specialized-mission-extendedrep-21 may09.pdf extended report 21 may 2009

[12]. "Life in the gaza strip six weeks after the armed conflict 27 dec2008 -17 jan 2009 "evidence from a household survey", Fafo institute for applied international studies, Oslo, Norway, http://www.unispal.un.org/UNiSPAl:NSF/0/5A91FECBD86B30F085257595B004E178A

[13]. " Human rights in Palestine and other occupied arab territories" ,report of the United nations fact finding mission on the Gaza conflict, http; \www.ohchr.org

[14]. Assessing the situation of women in Gaza, UNFPA ,10 march 2009, http; Ilwww.unep.org.com.

[15]. Ibid.

[16]. "Gaza - 1.5 million people trapped in despair", ICRC, June 2009, http://www.icrc.org/eng/ asserts/files/other/gaza-report-icrc.eng.pdf.

[17]. "WHO specialised health Mission to the Gaza Strip", http://www.who.int/hac/ crisis/international/ wbgs/gaza-specialized-mission-extendedrep-21may09.pdf extended report 21 may 2009.

[18]. "Life in the Gaza stripe six weeks after the armed conflict 27 Dec. 2008, 17 Jan.2004 Evidence from a household sample, Survey - A Summary" - Fafo Institute for Applied International Studies, $\quad h \mathrm{ttp}: / / \mathrm{www}$. unispal.un.org/UNiSPAl:NSF/0/5A91FECBD86B30F085257595B0 04E178A.

[19]. "Environmental Assessment of the Gaza Strip, following the escalation of hostilities in Gaza Dec.2008 - Jan.2009", UNEP, http://www.unep.org/pdf/dmb/UNEP-Gaza-EA.pdf.

[20]. "World Bank "Fact Sheet : Gaza Strip Water and Sanitation Situation", January 7. 2009, http://web.worldbank.org/WBSITE/EXTERNAL/COUNTRIES/NEXAEXT/WESTBANKGAZ ATXTN/O content mdk : 22026701 menuPK:2943 83 Page PK 2865066PiPk2865079 the site pk: $294365,00 \mathrm{htm}$.

[21]. "Situation Report from the Humanitarian Coordinator", OCHA, January 6, 2009 cited in "Deprived and Endangered : Humanitarian Crisis in the Gaza Strip",http;।l www.hrw.org/ en/news/2009/ 01/12 deprived-and-endangered-humanitariancrisis-gaza-strip.

[22]. "Field Update on Gaza from the Humanitarian Coordinator", OCHA, January 9, 2009 cited in "Deprived and Endangered : Humanitarian Crisis in the Gaza Strip" Jan.13, 2009, HRW ,www.hrw.org/ en/news/2009/01/12 deprived-and-endangered-humanitariancrisis-gaza-strip.

[23]. "Gaza - 1.5 million people trapped in despair", ICRC, report, June 2009, http://www.icrc.org/ eng/assets/files/other/gaza-report/icrc/eng.pdf.

[24]. "Gaza Electricity, water and sewage systems on verge of collapse", Gisha, January 4, 2009, http://gisha.org/indexphp?intlanguage=2*int Item Id = 1429 and int Site SN $=113$, cited in "Deprived and Endangered humanitarian crisis in the Gaza Strip",http;। www.hrw.org/en/news/ 2009/01/12 deprived-and-endangered-humanitariancrisis-gaza-strip.

[25]. "Situation Report from the humanitarian coordinator", OCHA, Jan. 7, 2009 cited in "Deprived and Endangered humanitarian crisis in the Gaza Strip",http; \ www.hrw.org/en/news/ 2009/01/12 deprived-and-endangered-humanitariancrisis-gaza-strip.

[26]. Ibid.

[27]. "Rain of Fire Israel's Unlawful use of White phosphorous in Gaza", Human Rights Watch, March 2009, http://www.hrw.org/en/reports/2009/03/25/rain-fire.

[28]. "Life the Gaza Strip six weeks after the armed conflict 27 Dec., 2008 - 17 Jan., 2009 "Evidence from a household sample survey : A summary", Fafo Institute for Applied International Studies ,http://www. unispal.un.org/UNiSPAl:NSF/0/5A91FECBD86B30F08 5257595B004E178A. 
[29]. "The Palestinian National Early Recovery and Reconstruction Plan for Gaza 2009-2010, launched by the Palestinian National Authority at the International Conference in Support of the Palestinian Economy for the Reconstruction of Gaza in Sharm El-Sheikh", Egypt 2 March, 2009

[30]. "Life the Gaza Strip six weeks after the armed conflict 27 Dec., 2008 - 17 Jan., 2009 "Evidence from a household sample survey : A summary",Fafo Institute for Applied Internationa Studies, http://www.unispal.un.org/UNiSPAl:NSF/0/5A91FECBD86B30F08525 7595B004E178A

[31]. Ms. Karen Abu Zaid, Commissioner General, UNRWA, Personal Communication

[32]. The State of Nutrition Situation of West Bank and Gaza Strip, Palestinian National Assembly, World Health Organization and UNICEF, June 2005.

[33]. "WHO Specialized Health Mission to the Gaza Strip, Extended Report", Geneva 21 May 2009, http://www.who.int/hac/crisis/international/wbgs/gaza-specialisedmission-extendedrep21may09.pdf.

[34]. "Life in the Gaza Strip, six weeks after the armed conflict 27 Dec.2008 - 17 Jan., 2009, Evidence from a household Survey : A Summary", Fafo Institute for Applied International Studies.

[35]. http://www. unispal.un.org/UNiSPAl:NSF/0/5A91FECBD86B30F085257595B004E178A.

"WHO Specialized Health Mission to the Gaza Strip, Extended Report", Geneva 21 May 2009, http://www.who.int/hac/crisis/international/wbgs/gaza-specialisedmission-extendedrep21may09.pdf.

[36]. "Life in the Gaza Strip, six weeks after the armed conflict 27 Dec.2008 - 17 Jan., 2009, Evidence from a household Survey : A Summary, Fafo Institute for Applied International Studies",http://www.unispal.un.org/UNiSPAl:NSF/0/5A91FECBD86B30F085257595B004E $178 \mathrm{~A}$.

[37]. Merchandise Traffic and Humanitarian Aid Report; The Gaza Strip Weekly Report 26.04-0206-09, Coordination of Government Activities in the Territories, Ministry of Defense, Israel.

[38]. Through Women's Eyes, A PCHR report on the Gender-Specific impact and consequences operation cast lead, 2009, http://www.pchrgaza.org/files/reports/english/pdf-spec/ throughwomen's \%20eyes.pdf.

[39]. Ibid.

[40]. Ibid.

[41]. Ibid.

[42]. Ibid.

[43]. Ministry of Health in Gaza cited in "Through Women's Eyes, A PCHR reported on the Gender : Specific Impact and Consequences of Operation Cast Lead". Palestinian Centre for HumanRights, http://www.pchrgaza.org/files/reports/english/pdf-pec/throughwomen's\%20eyes.pdf. 